\title{
Effect of nicotine on gallbladder bile
}

\author{
ANGLO-DUTCH NICOTINE INTESTINAL STUDY GROUP \\ Michael RhODES MD, FreEK J ZiJlstra PhD, D Michael BRADBURN BM BCh, EMMANUEL D SRIVASTAVA MD, \\ APM van Dijk BSc, Michael AH Russell phD, Mark VAn Blankenstein mD, JH PAUl Wilson mD, \\ ADRIAN AlLEN PhD, JOHN RHODES MD
}

\begin{abstract}
M RHODES, FJ ZIJLSTRA, DM BRADBURN, ET AL, FOR THE ANGLO-DUTCH NICOTINE INTESTINAL STUDY GROUP. Effect of nicotine on gallbladder bile. Can J Gastroenterol 1994;8(5):333-338. Several studies have shown that symptomatic gallstones are largely a disease of nonsmokers, which raises the possibility that nicotine may protect against the formation of gallstones. To examine the effect of nicotine on the gallbladder, 32 rabbits were allocated to four groups: controls and three treatment groups in which nicotine tartarate at low, medium and high doses was administered subcutaneously via an osmotic minipump. After 14 days' treatment the gallbladder was removed and measurements made of gallbladder mucin synthesis, bile mucin concentration, bile acid concentration and cholesterol saturation. Serum nicotine concentrations ( $\mathrm{ng} / \mathrm{mL}$ ) were $( \pm$ SE) $0.4 \pm 0.1,3.5 \pm 0.4,8.8 \pm 0.8$ and $16.2 \pm 1.8$ in the controls and three treatment groups, respectively. Total bile acid concentration increased significantly in all three treated groups with the greatest increase in the group given low dose nicotine $(\mathrm{P}<0.001)$. Cholesterol saturation did not differ significantly in any group but soluble mucin concentration in gallbladder bile was significantly reduced ( $\mathrm{P}=0.013,95 \% \mathrm{CI}: 16$ to 111 ) with high dose nicotine. Gallbladder mucin synthesis, measured by ${ }^{3} \mathrm{H}$-glucosamine incorporation, did not change significantly with nicotine treatment. Subcutaneous nicotine 2.0 $\mathrm{mg} / \mathrm{kg} /$ day for 14 days significantly reduced the concentration of biliary mucin, which could potentially reduce cholesterol nucleation and subsequent gallstone formation. This may be one of the mechanisms responsible for the relative reduction in gallstone disease among smokers.
\end{abstract}

Key Words: Gallstone pathogenesis, Gallstones, Mucin, Nicotine

\section{Effet de la nicotine sur la bile, au niveau de la vesicule}

RÉSUMÉ : Selon diverses études, la cholélithiase symptomatique est, pour une bonne part, une maladie de non-fumeurs, ce qui soulève l'hypothèse d'une possible protection conférée par la nicotine contre la formation de calculs. Dans le cadre de cette étude sur l'effet de la nicotine sur la vésicule biliaire, 32 lapins continuer à la page prochaine

Departments of Surgery and Physiological Sciences, University of Newcastle upon Tyme, Newcastle upon Tyne, United Kingdom; Department of Gastroenterology, University Hospital of Wales, Cardiff, United Kingdom; Departments of Pharmacology and Internal Medicine 11 Erasmus University, Rotterrdam, The Netherlands; Imperial Cancer Research Fund Health Behaviour Unit, Institute of Psychiatry, London, United Kingdom

Correspondence: Professor John Rhodes, Department of Gastroenterology, University Hospital of Wales, Heath Park, Cardiff, Wales CF4 4XW. Telephone 0222-743292, Fax $0222-743821$

Received for publication December 21, 1993. Accepted June 20, 1994
$\mathrm{T}$ HE DEVELOPMENT OF GALLSTONES is influenced by many factors. In the western world diet and estrogen status are important predisposing factors. Estrogens increase the lithogenicity of bile, and gallstones are certainly more common in women, increasing in frequency with pregnancy, the oral contraceptive pill and menopausal estrogens (1).

Several studies have identified a relationship between cigarette smoking and gallstones (2-5). One of the more consistent findings is a relative reduction in the prevalence of gallstones among older smokers in contrast with an increased risk of stones in young patients who smoke. The reason for this dichotomy is not immediately apparent, but in young patients, smoking may simply serve as a marker for other factors that increase the risk of stones; these include birth control pill usage and pregnancy. Older patients who smoke have usually done so for most of their lives (5) and have a lower risk of gallstone disease compared with nonsmokers. In view of this, the possible mechanisms by which smoking may affect stone formation are of interest.

Smoking is known to reduce prostaglandin synthesis in many tissues throughout the body $(6,7)$ and this may change mucin secretion in the gallbladder or bile composition, both of which could influence gallstone formation $(8,9)$. We therefore examined the effect of nicotine on gallbladder bile biochemistry in an animal model. 
ont été répartis en quatre groupes : un groupe-témoin et trois groupes thérapeutiques auxquels du tartarate de nicotine a été administré par voie sous-cutanée en doses faible, moyenne et élevée, au moyen d'une mini-pompe osmotique. Après 14 jours de traitement, la vésicule a été enlevée et des spécimens ont été recueillis pour mesurer la synthèse de la mucine de la vésicule biliaire, la concentration de mucine biliaire, la concentration d'acide biliaire et la saturation en cholestérol. Les concentrations de nicotine sérique $(\mathrm{ng} / \mathrm{mL})$ ont été ( \pm ÉT) de $0,4 \pm 0,1,3,5 \pm 0,4,8,8 \pm 0,8$ et $16,2 \pm 1,8$ chez les témoins et dans les trois groupes traités respectivement. La concentration d'acide biliaire totale augmentait nettement dans les trois groupes traités, l'augmentation la plus marquée se trouvant dans le groupe ayant reçu la dose faible de nicotine $(\mathrm{P}<0,001)$. La saturation en cholestérol n'a pas différé de façon marquée d'un groupe à l'autre, mais la concentration de mucine soluble au niveau de la bile dans la vésicule biliaire était nettement moindre $(\mathrm{P}=0,013, \mathrm{IC} 95 \%: 16$ à 111) avec la nicotine à dose élevée. La synthèse de la mucine dans la vésicule biliaire mesurée par l'incorporation de ${ }^{3} \mathrm{H}$-glucosamine n'a pas changé considérablement avec le traitement par nicotine. La nicotine sous-cutanée à raison de $2,0 \mathrm{mg} / \mathrm{kg} / \mathrm{jour}$ durant 14 jours a nettement diminué la concentration de mucine biliaire, ce qui pourrait réduire la nucléation du cholestérol et la formation de cholélithiase subséquente. Il pourrait s'agir là de l'un des mécanismes responsables de la réduction relative de cholélithiase parmi les fumeurs.

\section{ANIMALS AND METHODS}

Thirty-two male New Zealand white rabbits, weighing between 2 and $2.5 \mathrm{~kg}$, were allocated to four groups: control and three treatment groups, with eight rabbits in each group. Nicotine hydrogen tartarate (BDH Ltd, Poole, England) was given over 14 days by subcutaneous infusion in doses equivalent to $0.5,1.25$ and $2 \mathrm{mg} / \mathrm{kg} /$ day of nicotine base in the three treatment groups, respectively, and compared with saline administration in controls. An Alzet osmotic minipump (SAVO, Kisslegg im Allgäu, Germany), model 2ML2, with infusion rate $5 \mu \mathrm{L} / \mathrm{h}$ was implanted under halothane anesthesia, and each animal was housed separately with food and water supplied freely. One millilitre of blood was taken from the ear vein initially and on day 6 and 14 for measurement of plasma nicotine (10). Rabbits were weighed initially and at 14 days, when they were sacrificed and had their gallbladder bile aspirated and gallbladder removed.

Measurement of mucin concentration in bile and mucin synthesis: Measurement of mucus glycoprotein in bile was undertaken using a modified 'slot blot' technique (11). This method can be used to measure mucin glycoprotein of biliary origin, purified from human bile and gallstones (12). The rate of mucin synthesis by gallbladder mucosa was measured as previously described $(13,14)$. Mucosal explants were cultured for $24 \mathrm{~h}$ at $37^{\circ} \mathrm{C}$ in medium containing $\mathrm{D}\left[{ }^{3} \mathrm{H}\right]$-glucosamine and in an atmosphere of $95 \%$ oxygen and 5\% carbon dioxide. Tissues underwent papain digestion for $72 \mathrm{~h}$ to isolate carbohydrate-containing segments of mucin, followed by exhaustive dialysis to remove low molecular weight material before measurement of ${ }^{3} \mathrm{H}$-glucosamine incorporation. This procedure has previously been shown to isolate mucin type glycoproteins free from other glycoconjugates without significant loss of mucin carbohydrate. Radioactivity incorporated into mucin type glycoprotein was expressed as femtomol ${ }^{3} \mathrm{H}$-glucosamine incorporated per gram wet weight (ww) of mucosa.

Measurement of cholesterol, phospholipid and bile salts: Bile salts were measured by the 3-hydroxysteroid dehydrogenase technique (15). Phospholipid (16) and cholesterol (17) were measured enzymatically. The cholesterol saturation index was calculated according to Admirand and Small (18). Measurement of eicosanoids: Tissue samples from the gallbladder (50 to 100 $\mathrm{mg}$ ww) were stored at $-70^{\circ} \mathrm{C}$ for subsequent analysis of eicosanoids. Previous studies have shown that eicosanoid synthesis is unaffected by storage at $-70^{\circ} \mathrm{C}(19)$. On analysis each sample was homogenized in $1 \mathrm{~mL}$ of KrebsHenseleit buffer ( $\mathrm{pH}$ 7.4) by means of an Ultra-Tuffax homogenizer (Polytron, Kinematica, Luzern, Switzerland) for $20 \mathrm{~s}$ on melting ice. Total protein was determined by a microscale method using an ELISA reader at $600 \mathrm{~nm}$ (Instruchemie, Hilversum, The Netherlands). Each tissue sample was incubated with $4.6 \times 10^{3} \mathrm{~Bq}\left[1-{ }^{14} \mathrm{C}\right]$-arachi-

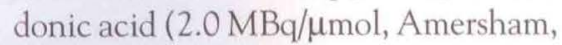
Buckinghamshire, United Kingdom) together with $2 \mu \mathrm{M}$ calcium ionophore A23187 (Sigma, Missouri) at $37^{\circ} \mathrm{C}$ for 15 mins. Then ${ }^{3} \mathrm{H}$-labelled compounds of prostaglandins 6-keto-prostaglandin F (PGF) $1 \alpha, \mathrm{PGF}_{2} \alpha$ and PGE2, thromboxane $B_{2}$, hydroxyheptadecatrienoic acid (HHT) and 15-hydroxyeicosatetraenoic acid (HETE) (Amersham) were added as chromatographic standards and for the determination of recovery. Samples were centrifuged for 2 mins at $1600 \mathrm{~g}$ at $4^{\circ} \mathrm{C}$. The supernatant was applied to a Sep Pak $\mathrm{C}_{18}$ cartridge (Millipore Waters Ass, Etten-Leur, The Netherlands), diluted with ethanol and dried with $\mathrm{Sa}$ vant Speed Vac concentrator (New Brunswick Sci, Nijmegen, The Netherlands). The pellet was dissolved in $250 \mu \mathrm{L}$ methanol and filtered through an Anotop $0.2 \mu \mathrm{m}$ filter (Merck, Darmstadt, Germany) into a high performance liquid chromatographic (HPLC) polypropylene microvial. One hundred microlitres were injected onto two combined Nucleosil $5 \mathrm{C}_{18}$ HPLC columns ( $3 \times 20 \mathrm{~mm}$, Chrompack, Middelburg, The Netherlands). HPLC was performed with a Hewlett-Packard 1084B liquid chromatograph with a dual pumping system (Oregon). Radioactivity was measured on-line with a Berthold LB506C monitor (Wildbad, Germany). The solvent system contained a gradient of $0.12 \%$ trifluoroacetic acid and $0.2 \%$ triethylamine in water $(\mathrm{pH}$ 3.0) and acetonitrile (Lichrosolv, Merck, Darmstadt, Germany). The flow rate was $0.5 \mathrm{~mL} / \mathrm{min}$ at $37^{\circ} \mathrm{C}$. Picofluor (Canberra Packard Benelux NV, Tilburg, The Netherlands) was used as a premixed scintillator at a flow rate of $2.25 \mathrm{~mL} / \mathrm{min}(19-21)$.

Statistics: Groups were compared using Student's $t$ test; for nonparametric data the Mann-Whitney U test was em- 
ployed. Correlation coefficients were calculated using a standard linear regression analysis.

\section{RESULTS}

The mean concentrations of serum nicotine in $\mathrm{ng} / \mathrm{mL}$ ( $\pm \mathrm{SE}$ ) from two measurements on day 6 and day 14 were $0.4 \pm 0.1,3.5 \pm 0.4,8.8 \pm 0.8$ and $16.2 \pm 1.8$ in the control and three nicotinetreated groups, respectively (Table 1). This compares with a serum nicotine level between 5 and $60 \mathrm{ng} / \mathrm{mL}$ in human smokers. Compared with day 6 , values on day 14 had fallen between 12 and $36 \%$, and the difference reached significance in the medium dose nicotine group $(\mathrm{P}=0.026,95 \% \mathrm{CI}: 0.5$ to 7.02). Weight gain during the 14 day study was similar in the four groups. Controls increased their weight by a mean ( \pm SE) of $276 \pm 44 \mathrm{~g}$ compared with to $276 \pm 28 \mathrm{~g}$ in the low dose group, $301 \pm 97 \mathrm{~g}$ in the medium dose group and $250 \pm 39 \mathrm{~g}$ in the high dose nicotine group.

Total bile acid concentration increased significantly in all three nicotine-treated groups with the greatest increase in the group given low dose nicotine (Table 2, Figure 1). Cholesterol concentration in the gallbladder bile of both controls and treated animals was very low; concentration did not exceed $1 \mathrm{mmol} / \mathrm{L}$ and cholesterol saturation was less than $3 \%$ in all cases. There was no significant difference in cholesterol concentration or saturation between controls and treated animals.

The concentration of gallbladder bile mucin was decreased in the nicotine-treated animals, and this decrease reached significance in the high dose nicotine group ( $\mathrm{P}=0.013,95 \% \mathrm{CI}$ : 16 to 111) (Table 2). The decrease in bile mucin was greatest in the high dose treatment group and was linearly related to the serum nicotine concentration $(r=0.44, \mathrm{P}<0.05)$ (Figure 2$)$. There was no significant reduction in biosynthesis of mucin type glycoprotein by explanted gallbladder mucosa (Table 2), nor were there significant changes in mucosal eicosanoid levels in any of the treatment groups (Table 3), although there was a nonsignificant trend for PGF2 $\alpha$ to increase in the high

TABLE 1

Plasma nicotine concentrations in controls and three nicotine treatment groups given $0.5,1.25$ and $2 \mathrm{mg} / \mathrm{kg} /$ day, respectively, for 14 days with measurements on days 6 and 14

\begin{tabular}{lcccc}
\hline & Control & $\begin{array}{c}\text { Low dose } \\
(\mathbf{n g} / \mathbf{m L})\end{array}$ & $\begin{array}{c}\text { Medium dose } \\
(\mathrm{ng} / \mathrm{mL})\end{array}$ & $\begin{array}{c}\text { High dose } \\
(\mathrm{ng} / \mathrm{mL})\end{array}$ \\
\hline Day 6 & $0.3 \pm 0.07$ & $4.0 \pm 0.4$ & $10.8 \pm 1.2$ & $17.3 \pm 1.9$ \\
Day 14 & $0.4 \pm 0.11$ & $3.0 \pm 0.5$ & $6.9 \pm 1.0$ & $15.2 \pm 2.2$ \\
Mean of days 6 and 14 & $0.4 \pm 0.1$ & $3.5 \pm 0.4$ & $8.8 \pm 0.8$ & $16.2 \pm 1.8$ \\
\hline
\end{tabular}

All values are expressed as mean \pm SE. Each group contained eight rabbits

TABLE 2

Concentration of mucin in bile and synthesis rates of mucin by gallbladder mucosa in controls and three nicotine treatment groups given $0.5,1.25$ and 2 $\mathrm{mg} / \mathrm{kg} /$ day of nicotine, respectively, for 14 days

\begin{tabular}{lcccc}
\hline & Control & $\begin{array}{c}\text { Low dose } \\
(\mathrm{ng} / \mathrm{mL})\end{array}$ & $\begin{array}{c}\text { Medium } \\
\text { dose }(\mathrm{ng} / \mathrm{mL})\end{array}$ & $\begin{array}{c}\text { High dose } \\
(\mathrm{ng} / \mathrm{mL})\end{array}$ \\
\hline Bile mucin concentration $(\mu \mathrm{g} / \mathrm{mL})$ & $274 \pm 16$ & $257 \pm 14$ & $253 \pm 9.4$ & $211 \pm 15^{*}$ \\
Mucin synthesis & $87 \pm 11.6$ & $98 \pm 16.4$ & $96 \pm 8.7$ & $69 \pm 16.8$ \\
Bile acids (mmol/L) & $29.3 \pm 1.0$ & $42.9 \pm 0.7^{* * *}$ & $38.4 \pm 1.8^{* *}$ & $34.2 \pm 1.1^{* * *}$ \\
Cholesterol (mmol/L) & $0.75 \pm 0.58$ & $1.34 \pm 0.98$ & $0.63 \pm 0.45$ & $0.59 \pm 0.67$ \\
Phospholipid (mmol/L) & $0.24 \pm 0.07$ & $0.25 \pm 0.08$ & $0.16 \pm 0.11$ & $0.18 \pm 0.09$ \\
\hline
\end{tabular}

Mean synthesis rates are given as $\mathrm{D}\left(6^{3}-\mathrm{H}\right)$-glucosamine disintegrations $/ \mathrm{min} \times 10^{3} / \mathrm{g}$ wet weight. Each group contained eight rabbits. Significant differences: " $P=0.013 ;{ }^{* *} P<0.01$; ${ }^{* * *} P<0.001$

and medium dose nicotine groups $(\mathrm{P}=0.06$, Mann-Whitney $\mathrm{U}$ test) (22).

\section{DISCUSSION}

As far as we are aware this is the first study to examine the effect of nicotine on gallbladder bile composition. There were significant changes in the composition of bile after 14 days of subcutaneous nicotine with a reduction in biliary mucin and an increase in total bile salt concentrations. If these changes were also to occur in humans as a result of smoking, they may protect against gallstone formation by decreasing cholesterol nucleation and increasing cholesterol solubility.

Mucus glycoprotein appears to have a role in the formation of cholesterol gallstones. It makes up the skeleton of cholesterol stones (23) and may contribute to the early stages of stone formation (24); it also has the ability to nucleate cholesterol from supersaturated bile $(25,26)$. In both the cholesterol-fed rabbit (27) and prairie dog model of cholelithiasis (8), a high cholesterol diet induces increased gallbladder glycoprotein synthesis and secretion (28-30). These changes in glycoprotein metabolism antedate the formation of stones. Thus, any treat- ment that reduces bile mucin concentrations may reduce cholesterol nucleation and subsequent gallstone formation. Similarly the rise in total bile acid concentration in bile tends to reduce gallstone formation by increasing cholesterol solubility. This has been the basis for several large studies into the role of oral bile salts in the dissolution of cholesterol gallstones (31-34). Subcutaneous nicotine therefore has two actions that theoretically could reduce gallstone formation.

Gallbladder mucin has been isolated and characterized from humans, pigs and cattle. The typical structure of mucin type glycoprotein involves a long glycosylated segment resistant to proteolytic digestion. Use is made of this feature in the estimation of mucin glycoprotein during isolation of mucus from other proteins in bile. Exhaustive papain digestion of the solution leads to retention of mucus glycoproteins alone on the filter paper, which are then stained with periodic acid-Schiff stain (PAS) to quantitate the amount present. The large molecular weight proteins are transferred from the filter paper after papain digestion for measurement on a slot blot.

Studies with human and pig bile, 


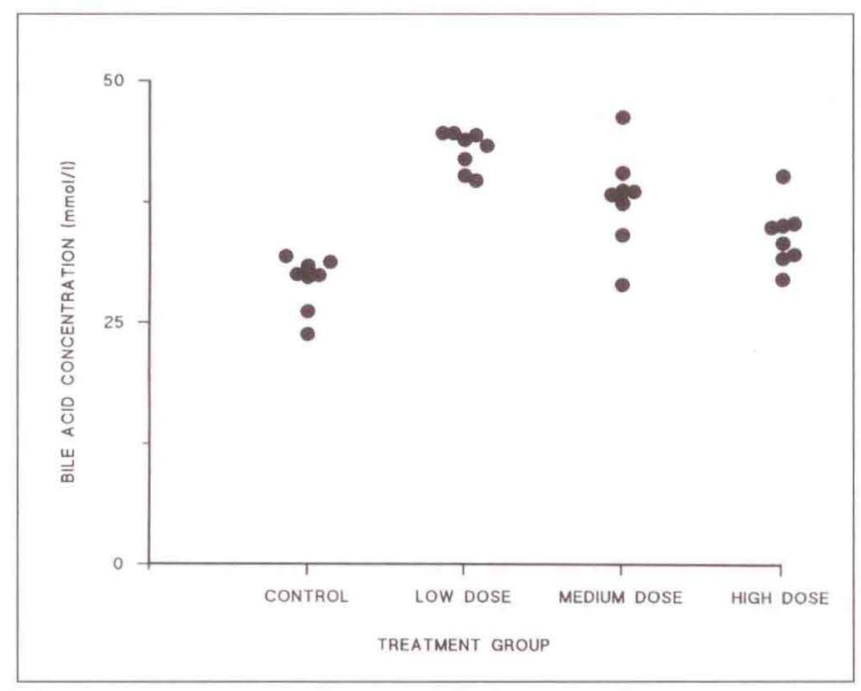

Figure 1) Effect of subcutaneous nicotine on gallbladder bile acid concentration in the four animal groups, with each animal represented as a single dot. Mean bile acid concentrations in controls were $29.3 \mathrm{mmol} / \mathrm{L}$ compared with $42.9 \mathrm{mmol} / \mathrm{L}$ in the low dose nicotine group $(P<0.001$, $95 \% \mathrm{CI}: 11.0$ to 16.3$), 38.4$ in the medium dose group $(\mathrm{P}<0.01,95 \%$ $\mathrm{CI}: 4.5$ to 13.7$)$ and 34.2 in the high done group $(P<0.01,95 \% \mathrm{CI}$ : 1.7 to 8.2 )

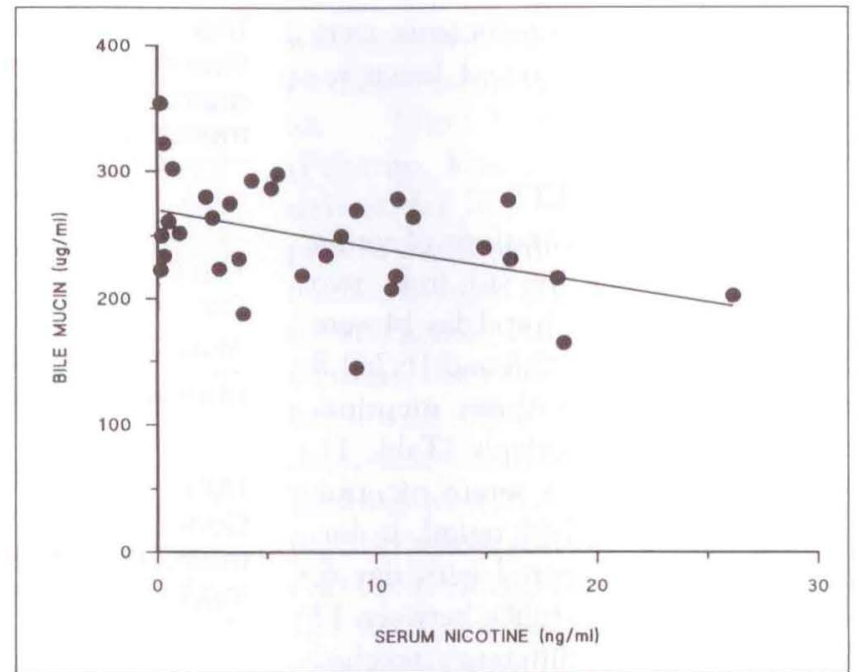

Figure 2) Correlation between serum nicotine and concentration of gallbladder bile mucin. Each animal is represented by a single dot. Linear correlation is at the level of $r=0.44, P<0.05$

TABLE 3

Concentrations of gallbladder wall eicosanoids in controls and three nicotine treatment groups given $0.5,1.25$ and $2 \mathrm{mg} / \mathrm{kg} /$ day, respectively, for 14 days

\begin{tabular}{lcccc}
\hline $\begin{array}{l}\text { Eicosanoids } \\
\text { (dpm/mg wet weight) }\end{array}$ & Control & $\begin{array}{c}\text { Low dose } \\
(\mathrm{ng} / \mathrm{mL})\end{array}$ & $\begin{array}{c}\text { Medium dose } \\
(\mathrm{ng} / \mathrm{mL})\end{array}$ & $\begin{array}{c}\text { High dose } \\
(\mathrm{ng} / \mathrm{mL})\end{array}$ \\
\hline $\mathrm{PGF}_{2} \alpha$ & $93.2 \pm 18.0$ & $45.0 \pm 5.9$ & $190.8 \pm 36.7$ & $141.3 \pm 11.8$ \\
$\mathrm{PGE}_{2}$ & $30.1 \pm 5.7$ & $29.5 \pm 12.0$ & $44.7 \pm 8.3$ & $28.0 \pm 5.8$ \\
6KPGF $\alpha$ & $8.6 \pm 1.7$ & $9.0 \pm 3.1$ & $14.9 \pm 3.8$ & $15.4 \pm 3.9$ \\
HHT & $39.1 \pm 10.1$ & $37.2 \pm 9.6$ & $64.7 \pm 4.8$ & $40.3 \pm 3.3$ \\
\hline
\end{tabular}

dpm Disintegrations per minute: HHT Hydroxyheptadecatrienoic acid; PG Prostaglandin. Each group contained eight rabbits. Treatment groups were compared with the control using the Mann Whitney $U$ test for nonparametric data. None of the comparisons revealed significant differences at $P=0.05$

after papain digestion, show that mucin glycoprotein is the only remaining component. However, papain digestion of radiolabelled mucosal explants does not exclude the presence of membrane glycoproteins with a mucin type structure. However, since there was no change in total incorporation into papain digested radioactive explants it is reasonable to assume that there is no significant difference in the biosynthesis of mucin glycoproteins by the gallbladder mucosa following nicotine administration.

The increased bile acid concentration is likely to reflect an increased bile acid pool in nicotine-treated animals because the animals were all killed in the fasting state and the volume of gall- bladder bile was similar in the groups. This could be explained by the fact that nicotine decreases bile (35) and bile acid (36) secretion with consequent decreased cycling of enterohepatic bile acids, resulting in an increased bile acid pool (37). Although the rise in total bile acid concentration in bile tends to reduce gallstone formation by increasing cholesterol solubility, this effect may be negatively influenced by prolonged stasis in the gallbladder as a consequence of decreased cycling of bile acids; these changes could increase the risk of stone formation through mechanisms that also apply in pregnancy - in the latter situation due to high estrogen levels $(38,39)$.

Previous epidemiological studies as- sessing the possible role of smoking in gallstone disease have given conflicting results. Two recent case control studies $(5,40)$ showed a significantly increased risk of gallstones in nonsmokers, particularly women. In contrast, the Framingham study (2), which involved over 5000 subjects, concluded that smoking was not appreciably related to gallstone disease. Other surveys that have examined the relationship between symptomatic gallbladder disease and smoking have failed to show a relationship; these include the Boston Collaborative Drug Surveillance Program (41), a case control survey by Diehl et al (42) and a cohort study by Ramcharan (43). In contrast, studies by Pettiti et al (44), Layde et al (45) and Diehl et al (46) suggest a small increased risk of symptomatic gallstones among current smokers and ex-smokers. The apparent dichotomy in gallstone prevalence between younger and older smokers may well result from the varying effects on lithogenesis of mucin, bile acid pool size and gallbladder motility in different age groups.

The action of nicotine to reduce gallbladder bile mucin and increase bile acid concentrations may partially account for the findings of those authors $(2,5,46)$ who found that gallstone dis- 
ease was less prevalent among long term smokers. Although it is unlikely that these findings have therapeutic implications, they may add to our understanding of factors that influence gallstone pathogenesis.

ACKNOWLEDGEMENTS: This study was approved by the Animal Experimental Committee of the Erasmus University of Rotterdam. We are grateful to Mrs J de Kam in the laboratory of experimental surgery for implantation of the minipumps and Miss $\mathrm{H}$ Sampson for plating out the gallbladder explant cultures during the study. Mr M Rhodes and Mr DM Bradburn were supported by the University of Newcastle upon Tyne, William Edmund Harker bequest.

\section{REFERENCES}

1. Scragg RKR, MacMichael AJ, Baghurst PA. Oral contraceptives, pregnancy and endogenous oestrogen in gallstone disease - a case-control study. Br Med J 1984;288:1795-9.

2. Friedmann GD, Kannel WB, Dawber TR. The epidemiology of gallbladder disease: Observations in the Framingham study. J Chronic Dis 1966;19:273-92.

3. Jorgensen T. Gallstones in a Danish population. Relation to weight, physical activity, smoking, coffee consumption and diabetes mellitus. Gut 1989;30:528-34.

4. Layde PM, Vessey MP, Yeates D. Risk factors for gallbladder disease. A cohort study of young women attending family planning clinics. J Epidemiol Community Health 1982;36:274-8.

5. Rhodes M, Venables CW . Symptomatic gallstones - a disease of nonsmokers? Digestion 1991;49:221-6.

6. Quimby GF, Bonnice CA, Burstein SH, Eastwood GL. Active smoking depresses prostaglandin synthesis in human gastric mucosa. Ann Intern Med 1986;104:616-9.

7. Motley RJ, Rhodes J, Williams G, Tavares IA, Bennett A. Smoking eicosanoids and ulcerative colitis. J Pharm Pharmacol 1990;42:288-9.

8. Lee SP, Carey MC, LaMont JT. Aspirin prevention of cholesterol gallstone formation in prairie dogs. Science 1981;211:1429-31.

9. Hood K, Gleason D, Ruppin DC, Dowling RH. Prevention of gallstone recurrence by non-steroidal anti-inflammatory drugs. Lancet 1988;ii:1223-5.

10. Feyerabend C, Russell MAH. A rapid gas liquid chromatographic method for the determination of cotinine and nicotine in biological fluids. J Pharm Pharmacol 1990;42:450-2.

11. Thornton DJ, Holmes DF, Sheehan JK, Carlstedt I. Quantitation of mucus glycoproteins blotted on to nitrocellulose membranes. Anal Biochem 1989;182:160-4.

12. Pearson JP, Kaura R, Taylor W, Allen A. The composition and polymeric structure of mucus glycoprotein from human gallbladder bile. Biochim Biophys Acta 1982;706:221-8.

13. Hunter AC, Allen A, Garner A. Studies of mucus biosynthesis in the gastrointestinal tract. In: Chantler E, Ratcliffe NA, eds. Mucus and related topics. Symposium 43 of the Soc Exp Biol 1989:27-36

14. Rhodes M, Allen A, Dowling RH, Murphy G, Lennard TWJ. Aspirin in the prevention of gallstones inhibition of human gallbladder mucus synthesis in patients undergoing cholecystectomy. Gut 1992;33:1113-7.

15. Talalay P. Enzymatic analysis of steroid hormones. Methods Biochem Anal 1960;8:119-43.

16. Qureshi MY, Murphy GM, Dowling RH. The enzymatic determination of total phospholipids in bile and bile rich duodenal aspirates. Clin Chim Acta 1980;105:407-10.

17. Bolton CH, Nicholls JS, Heaton KW Estimation of cholesterol in bile: assessment of an enzymatic method. Clin Chim Acta 1980;105:225-30.

18. Admirand WH, Small DM. The physicochemical basis of cholesterol gallstones formation in man. J Clin Invest 1986;47:1043-52.

19. Zijlstra FJ, Van Dijk APM, Wilson JHP, et al. 15-HETE is the main arachidonic acid metabolite formed by human colonic tissues. Agents Actions 1992;35:C53-9.

20. Van der Ham AC, Kort WJ, Beijma AM, Zijlstra FJ, Vermeer MA, Jeekel J. Eicosanoid profile of healing colon anastomosis and peritoneal macrophages in the rat. Gut 1990;30:807-11.

21. Zijlstra FJ, Wilson JHP. 15-HETE is the main eicosanoid present in mucus of acute ulcerative colitis.

Prostaglandins Leukot Essen Fatty Acids 1991:43:55-9

22. Zijlstra FJ. Eicosanoid levels in broncho alveolar lavage fluid of young female smokers and non-smokers. Eur J Clin Invest 1992;22:301-6.

23. Womach NA, Zeppa R, Irvin GL. The anatomy of gallstones. Ann Surg 1963;157:670-86.

24. Pearson JP, Foster SNE. Mucus glycoprotein content of human cholesterol gallstones. Digestion 1987;36:132-40.
25. Levy PF, Smith BF, LaMont JT Human gallbladder mucin accelerates nucleation of cholesterol in artificial bile. Gastroenterology 1984;87:270-5

26. Smith BF. Human gallbladder mucin binds biliary lipids and promotes cholesterol crystal nucleation in model bile. J Lipid Res 1987:28:1088-97.

27. Freston JW, Bouchier IAD, Newman J. Biliary raucous substances in dihydrocholesterol-induced cholelithiasis. Gastroenterology 1969;57:670-8.

28. Lee SP. Hypersecretion of mucus glycoprotein by the gallbladder epithelium in experimental cholelithiasis. J Pathol 1981;134:199-207.

29. Lee SP, LaMont T, Carey MC. Role of gallbladder mucus hypersecretion in the evolution of cholesterol gallstones. J Clin Invest 1981;67:1712-23.

30. Doty JE, Pitt HA, Kuchenbecker SL, Porter-Fink V, Den Besten LW. Role of gallbladder mucus in the pathogenesis of cholesterol gallstones. Am J Surg 1983;145:54-60.

31. Datizinger RG, Hofmann AF, Schoenfield LJ, Thistle JL. Dissolution of cholesterol gallstones by chenodeoxycholic acid. N Engl J Med 1972;286:1-8.

32. Bell GD, Whitney B, Dowling RH Gallstone dissolution in man using chenodeoxycholic acid. Lancet 1972;i:1213-6.

33. Schoenfield LJ, Lachin JM, Baum RA, et al. Chendiol (chenodeoxycholid acid) for dissolution of gallstones: the National Cooperative Gallstone Study. Ann Intern Med 1981;95:257-82.

34. Gleeson D, Ruppin DC, Saunders A, Murphy GM, Dowling RH. Final outcome of ursodeoxycholic acid treatment in 126 patients with radiolucent gallstones. Q J Med 1990;76:711-29.

35. Konturek SJ, Solomon TE, McCreight WG, Johnson RL, Jacobson ED. Effects of nicotine on gastrointestinal secretions. Gastroenterology 1971;60:1098-105.

36. Demol P, Dozois RR, Go VLW, DiMango EP. Effects of nicotine on canine post-prandial pancreaticobiliary secretion and duodeno-pancreatic reflux. Gastroenterology 1981;80:A1134.

37. LaRusso NF, Szczepanik PA, Hofmann AF. Effect of deoxychoilic acid ingestion on bile acid metabolism and biliary lipid secretion in normal subjects. Gastroenterology 1977;72:132-40.

38. Everson GT, McKinley C, Lawson M, Johnson M, Kern F Jr. Gallbladder function in the human female: 
effect of the ovulatory cycle, pregnancy and contraceptive steroids. Gastroenterology 1982;82:711-9.

39. Kern F Jr, Everson GT, DeMark B, et al. Biliary lipids, bile acids and gallbladder function in the human female. J Clin Invest 1981;68:1229-42.

40. Pastides $\mathrm{H}, \mathrm{Tzonou} \mathrm{A}$, Trichopoulous D, et al. A case control study of the relationship between smoking, diet and gallbladder disease. Arch Intern Med 1990;150:1409-12.

41. Boston Collaborative Drug Surveillance Program. Oral contraceptives and venous

thromboembolic disease surgically confirmed gallbladder disease, and breast tumours. Lancet 1973;i:1399-404.

42. Diehl AK, Stern MP, Ostrower WS, Friedman PC. Prevalence of clinical gallbladder disease in MexicanAmerican, Anglo and Black women. Southern Med J 1980;73:438-42.

43. Ranwhuan S, et al. The Walnut Creek Study, vol II. Washington: Department of Health and Human Services, 1981

44. Pettiti DB, Friedman GD, Klatsky AL.
Association of a history of gallbladder disease with reduced concentration of high-density lipoprotein cholesterol. N Engl J Med 1981;304:1396-8.

45. Layde PM, Vessey MP, Yeates D. Risk factors of gallbladder disease: a cohort study of young women attending family planning clinics. J Epidemiol Community Health 1982;36:274-8.

46. Diehl AK, Hafner SM, Hazada HP, Stern MP. Coronary risk factors and clinical gallbladder disease: an approach to the prevention of gallstones? Am J Public Health $1987 ; 77: 841-5$ 


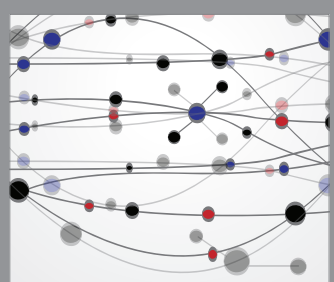

The Scientific World Journal
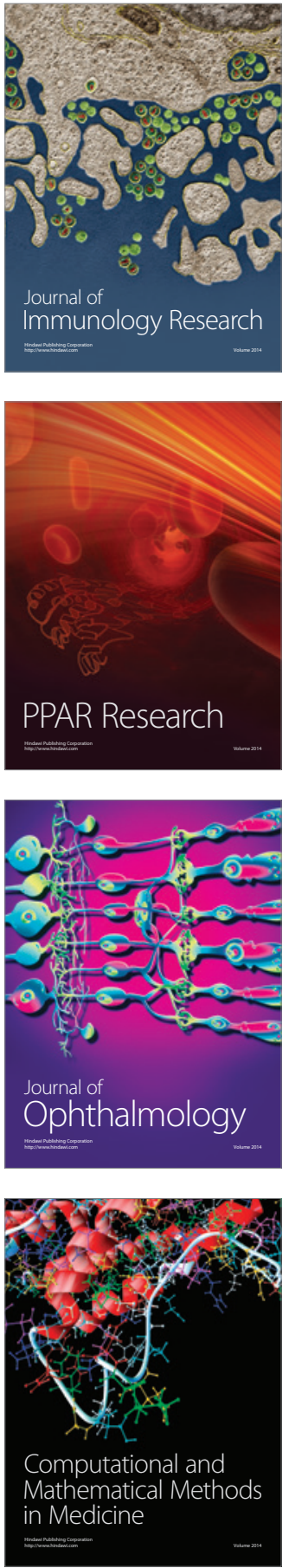

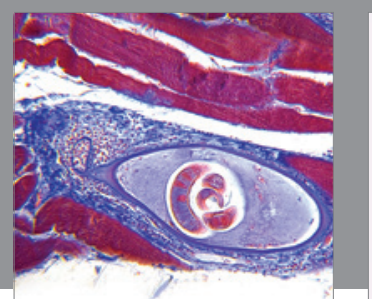

Gastroenterology Research and Practice

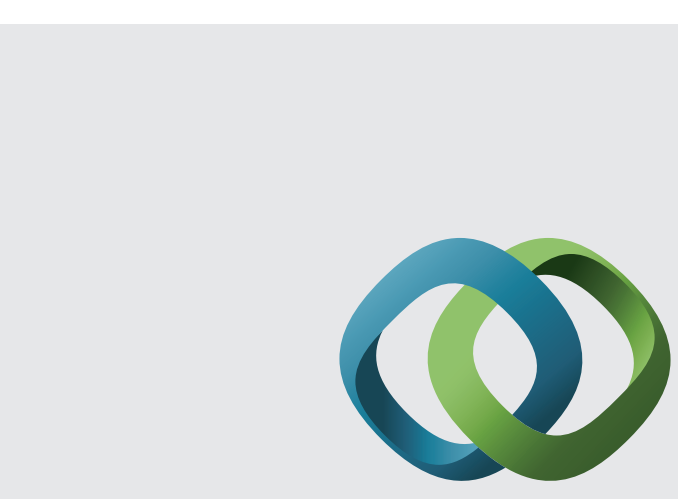

\section{Hindawi}

Submit your manuscripts at

http://www.hindawi.com
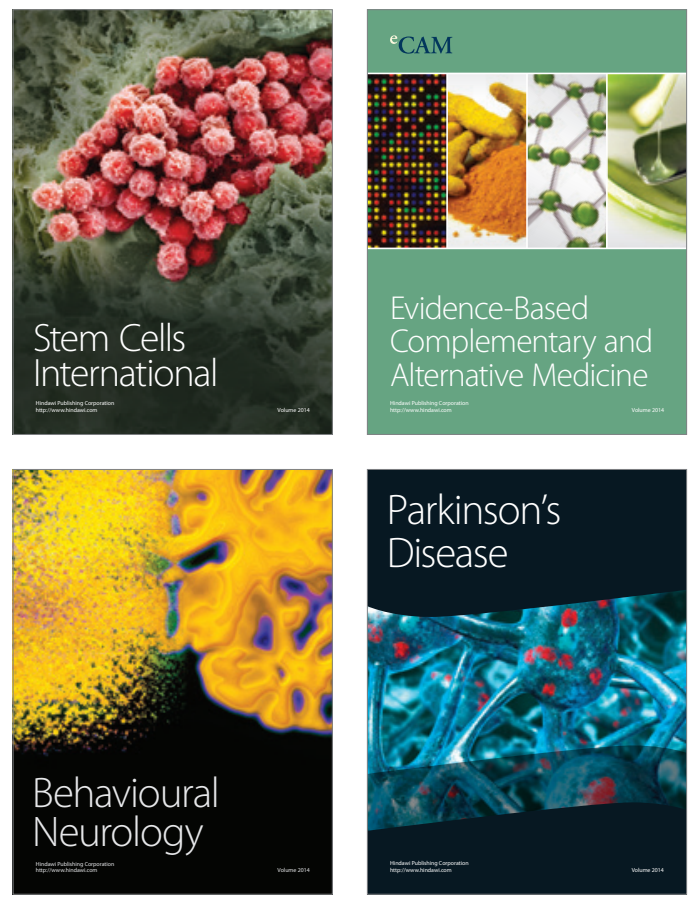
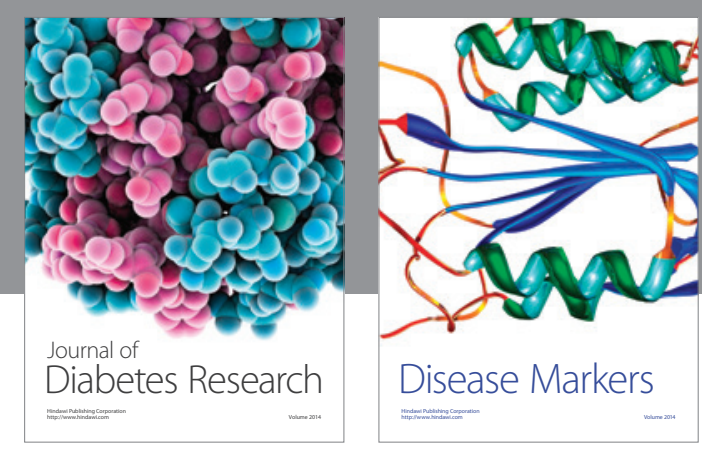

Disease Markers
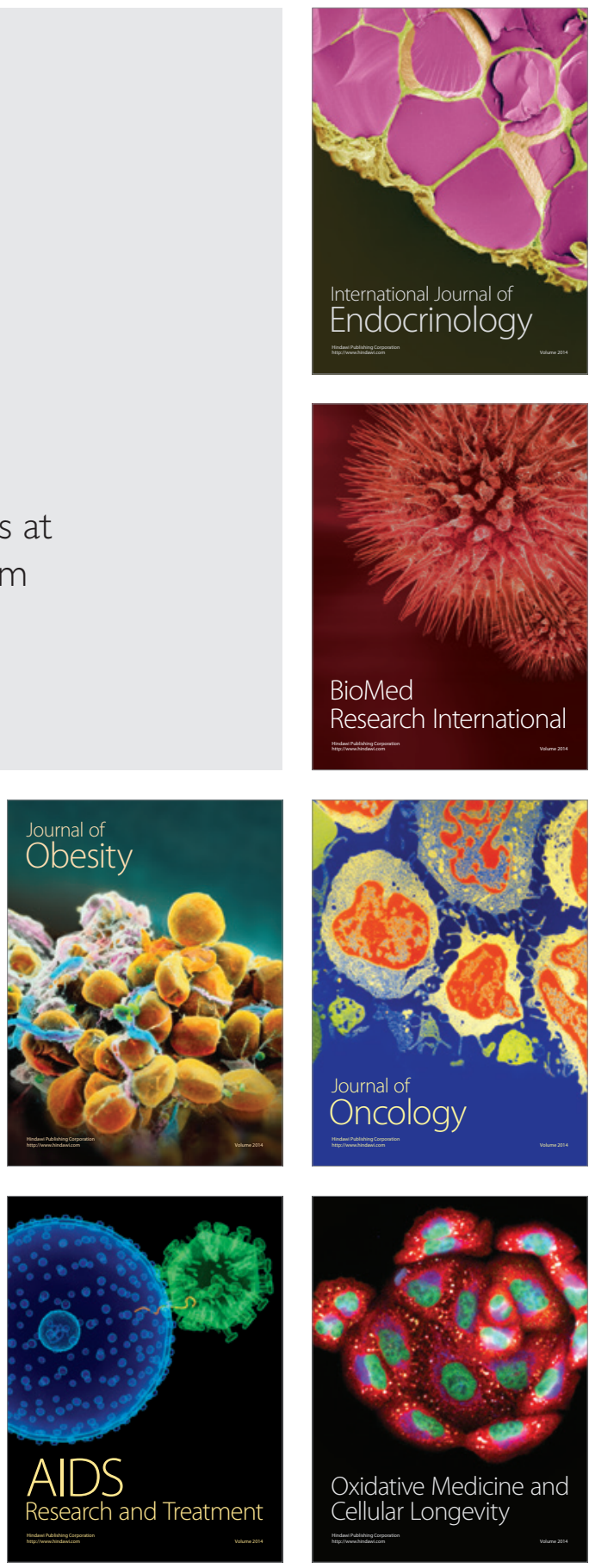